\title{
THE ACCOUNTING PROFESSIONS’ ROLE IN FINANCIAL MANAGEMENT SKILLS DEVELOPMENT OF SMALL BUSINESSES
}

\author{
Corrinna L Kirsten" \\ University of Stellenbosch \\ corinnakirsten@sun.ac.za
}

\author{
Johannes $\mathbf{R}$ Fourie+ \\ University of Stellenbosch \\ jrfourie@sun.ac.za
}

November 2011

\begin{abstract}
The support of small businesses in South Africa forms part of national strategies for creating jobs and wealth. To support small businesses, initiatives aimed at developing financial management skills (through training, support services and mentoring) are offered by various public and private sector organisations. Using a multi-case study design, this study explores the nature and extent of the financial management skills development interventions offered by a selection of Western Cape small business development support organisations. The study finds that the financial management skills development interventions on offer are generalised and limited in reach. Given the skills and expertise available in the South African accounting profession, the study also considers this profession's involvement in financial management skills development interventions. The study's main contribution is to demonstrate how members of the South African accounting profession can contribute to transferring financial management skills in a manner that will address the profession's corporate social responsibility.
\end{abstract}

\section{Keywords}

Accounting profession; Financial management skills; Corporate social responsibility (CSR); Financial management mentoring; Financial management support services; Financial management training; Small business development

\footnotetext{
\#Ms Corrinna Kirsten is a senior lecturer at the University of Stellenbosch, South Africa.

+ Mr Johannes Fourie is a lecturer at the University of Stellenbosch, South Africa.
} 


\section{INTRODUCTION AND BACKGROUND}

In 2010, the heads of the International Monetary Fund and the United Nations' (UN) International Labour Organisation noted that a lack of job creation was preventing economic recoveries in developed economies as well as emerging economies (UN, 2010). Similarly, the South African government's New Growth Path Framework identifies mass joblessness, inequality and poverty as core challenges facing South Africans (Government of South Africa, 2010:3). Small business development is an internationally recognised strategy for creating employment and reducing poverty. According to Israel M. Kirzner, the 2006 winner of the International Award for Entrepreneurship and Small Business Research (FSF-Nutek Award), small businesses and the entrepreneurs that run them play an important role in driving economic development, since they bring about economic renewal and support the effective functioning of competitive markets (Douhan, Eliasson \& Henrekson, 2007; Kirzner, 2009). In its comprehensive survey of 175000 entrepreneurs across 59 economies, including South Africa, the 2010 Global Entrepreneur Monitor (GEM) Report found that 250 million people were involved in early-stage entrepreneurial activities (Kelley, Bosma \& Amorós, 2011:7). The GEM survey findings show that an estimated 63 million people are expected to hire at least five employees over the next five years. Of these 63 million entrepreneurs, 27 million are expected to hire twenty or more employees over the next five years.

In an analysis of entrepreneurship across Africa, Kiggundu (2002:254) notes that most African countries recognise the need for strengthening small businesses as part of their respective poverty reduction strategies. Although South Africa is experiencing rising numbers of earlystage entrepreneurs (Kelley, et al., 2011:25), a mere increase in the number of entrepreneurs, and the resulting small businesses in an economy, is not sufficient to make a significant contribution to that economy. It follows that in order to realise its wealth and employment creation potential, South African small businesses require support to grow and survive. The South African government's New Growth Path Framework includes development and support of the relatively weak South African small business sector as part of its development policy package (Government of South Africa, 2010:20-21). The development policy package specifically notes that challenges in the form of a lack of financial and management skills in small businesses need to be addressed.

Owners of small businesses must possess financial management skills, as this is an aspect of management that increases start-up and new-business survival rates (Orford, Herrington \& Wood, 2004:4). Marx, De Swardt, Beaumont-Smith, Naicker and Erasmus (2004:7) find that, in order to perform the financial management functions of managing investments, financing and solvency (long-term goals), and ensuring profitability and positive cash flows (short-term goals), small business owners need to develop financial management skills. Given that many small businesses may initially focus on short-term survival, Schwarze (2008) summarises the critical financial management skills that small business owners need to manage their businesses successfully in the short term as the ability to: prepare a cash book; prepare accounts receivable records; perform proactive debtor management and records of inventory; perform a break-even analysis; and prepare and manage a cash budget. Record-keeping also forms an integral part of financial management, and, in addition, small businesses need to draw up and interpret financial statements, which will assist in making investment and financing decisions and managing solvency. Maas and Herrington (2006:71) identified education and training and support services provided by, for example, accounting clinics as small business support interventions to improve financial management skills. Orford, et al. (2004:53) identified 
targeted training and experienced mentoring as another effective type of intervention. These three types of financial management interventions: training, support services and mentoring could thus assist start-ups and existing micro-enterprise owners in developing their financial management skills.

Currently, a range of public and private sector organisations aim to address the challenge of generalised entrepreneurial and small business training, support services and mentoring. Officially the Minister in the Department of Trade and Industry (DTI) is tasked with the development and support of small businesses in terms of the National Small Business Act (Government of South Africa, 1996). The national agency responsible for supporting small businesses is the Small Enterprise Development Agency (DTI, 2003:47). At provincial level in the Western Cape, the Western Cape Department of Economic Development and Tourism was also involved in small business development through initiatives such as Red Door (Provincial Government of the Western Cape, 2011). Writers of the GEM report 2006 proposed that stakeholders such as tertiary training institutions, large businesses and smaller companies should become more involved in the process of small business development and support (Maas \& Herrington 2006:72).

The private sector has also been identified as a role-player in small business development and support by government (DTI, 2003:9). In the South African private sector, a strong pool of financial management skills is concentrated within the accounting profession. This strong pool of skills and expertise makes the South African accounting profession an important role- player when addressing the lack of financial management skills and expertise in small businesses referred to in the South African government's New Growth Path framework (Government of South Africa, 2010). In reality, however, many small businesses are excluded from the accounting profession's pool of skills and expertise, as many small businesses cannot afford the commercial fees charged by accounting professionals.

The challenge small businesses face in affording access to the accounting profession's services presents the accounting profession with an opportunity to address its corporate social responsibility (CSR). In broad terms, CSR refers to the view that business has a responsibility towards society that extends beyond its obligation to its shareholders (Visser, Matten, Pohl \& Tolhurst, 2010: 106-113; Crowther \& Aras, 2008: 28-31). Visser, et al. (2010:106) state that CSR can be seen to encompass 'economic, legal, ethical and discretionary or philanthropic expectations that society has of organisations at a given point in time'. In addition to CSR's linkage to managing societal expectations, Porter and Kramer (2006) propose that if CSR is approached strategically, it can benefit business through increasing its competitive context, i.e. adding a social dimension to its value proposition. In other words, clients and other stakeholders will attach greater value to the financial management services offered by the accounting profession. Strategically approached CSR will also contribute more significantly to societal progress as it is better integrated with companies' business model (Porter \& Kramer, 2006: 89-91). They argue that CSR can contribute to the competitive success of businesses through better integration with society. Historically, the South African accounting profession's CSR involvement with small businesses has been through discretionary or philanthropic small business development activities. Examples of professional accounting firms, accountants in their individual capacity and professional accounting bodies participating in various small business development initiatives on non-commercial terms exist. Such small business development initiatives, however, remain limited in existence and reach. There is also little apparent collaboration and coordination between members of the accounting profession and non-accounting organisations mandated to develop small businesses. According to Berry, Von 
Blottnitz, Cassim, Kesper, Rajaratnam and Van Seventer (2002:43), a lack of collaboration and coordination can result in a replication of services. Through B-BBEE legislation, and more specifically the Chartered Accountancy Sector Code for B-BBEE which was finalised in 2007 (gazetted 10 May 2011), the accounting profession's CSR involvement has been legally negotiated (Hamann, 2006: 180-181; Terry, 2008: 163-166). B-BBEE legislation allows accounting firms to obtain points on its $B-B B \varepsilon \varepsilon$ scorecards in exchange for monetary and nonmonetary contributions to the development of black-owned small businesses in South Africa (DTI, 2007: 65-69). Examples of small business development initiatives stemming from B-BBEE legislation include the South African Institute of Chartered Accountants' (SAICA's) HOPE Factory and the Black Entrepreneur Initiative (SAICA, 2011; SAICA Enterprise Development, 2011).

Hamann (2006: 179-180) sets out a research agenda for CSR in South Africa. He argues that CSR research should address specific and relevant Southern African development challenges, which include, among other things, the role of business in supporting small business development. He also argues that due to the contradictions between the rhetoric and practice of CSR by business, research into understanding and addressing the practical challenges of implementing CSR is required (Hamann: 2006: 188-190). Against this research agenda, the contribution of this study would be to add to the body of knowledge relating to CSR in the South African business sector. This study will also inform how the South African accounting profession can practically get involved in small business development through contributing to financial management skills development.

Schwarze (2008) recommends that members of the accounting profession can play a pivotal role in training, and can support services and mentoring-type financial management skills development interventions. Considering the importance of financial management skills for small businesses and the accounting profession's potential to contribute to the development of such skills in South Africa, the following research questions can be formulated: 1) What is the current nature and extent of financial management interventions provided to small businesses by small business support organisations in South Africa? and 2) How can members of the accounting profession in South Africa make a meaningful contribution to assisting these small business support organisations in the development of the financial management skills required by small businesses? To address these questions this exploratory study will investigate the following:

- The nature and extent of financial management training, support services and mentoring initiatives that are provided to small businesses by selected small business support organisations in South Africa. Training, support services and mentoring are identified as the main types of interventions used for small business development, as described by Orford and Maas; and

- The nature and extent of the assistance these small business support organisations require from the accounting profession with regard to the training, support services and mentoring provided to small businesses, in order to identify practical ways in which the accounting profession can become involved as part of its CSR.

\section{RESEARCH DESIGN AND METHODOLOGY}

For the purposes of this exploratory study, a multiple-case study design using selected organisations that provide general support to small businesses in an urban area was used. A multiple-case study design is appropriate for exploring the nature and extent of financial 
management interventions for small businesses, as rich data was required to understand the complex social and organisational processes underlying these interventions (Cassell \& Symon, 2004:26); the intent of the research is descriptive (Benbasat, Goldstein \& Mead, 1987:373); and the purpose of the study is to gain an understanding of the structure of the interventions in order to develop hypotheses, models or theories (Scholtz \& Tietje, 2002:11) for the potential involvement of the accounting profession in financial management skills development for small businesses.

Cross-case comparisons were made to highlight the similarities and differences in the approaches taken by these small business support organisations regarding the financial management interventions they offer. This was done in order to understand the unique needs of each organisation in terms of the assistance required from members of the accounting profession. In selecting a sample for this study, purposive sampling was used, as it is appropriate when a statistical generalisation from the sample to population is not intended (Robson, 2002:265) and no exhaustive list of the population is available (Babbie \& Mouton, 2001:166). Eight general small business support organisations, with varying characteristics, which provide financial management training, support services and/or mentoring to small businesses in the Greater Cape Town area of the Western Cape, were selected for this study.

To ensure a spread across sectors, initiatives from the non-profit sector; the private sector and the government sector were selected. Initiatives that are driven by the accounting profession were purposely not selected, as these initiatives already have direct involvement and support from the accounting profession. By focusing on initiatives that operate outside the accounting profession, this study is able to inform the accounting profession's understanding of CSR expectations held by external societal stakeholders. The focus of this study is on organisations that offer general small business support. These organisations potentially do not have sufficient financial management skills and knowledge to effectively offer financial management training, support services and mentoring to small businesses and may require assistance from the accounting profession. Data was collected using extensive structured personal interviews which were conducted with senior-ranking representatives from each sampled organisation between December 2009 and May 2010. To limit subjectivity and accurate data capturing, all interviews were recorded and captured by two researchers.

\section{FINDINGS AND DISCUSSION}

\subsection{Introduction}

Data relating to the financial management interventions that each organisation offers and the assistance required by the accounting profession for these organisations is summarised in table format and supported by narratives where necessary.

\subsection{Profile of organisations}

In order to contextualise the various organisations' approach to financial management interventions, each organisation in the sample is profiled in TABLE 1. The sample of organisations selected consists of three government organisations, four not-for-profit organisations (NPOs) and one private sector organisation (PSO). Most of these organisations focus on general entrepreneurial development and support, except for organisation $G$, which 
specifically focuses on skills development for the unemployed, of which entrepreneurship is an element. Organisation $\mathrm{H}$ focuses on training educators on an entrepreneurial programme that it has developed for micro-enterprises. The government organisations are fully funded by the government, whereas NPOs receive funding from a variety of sources. Most organisations either don't charge a fee to their clients for the interventions, or charge only a nominal commitment or subsidised fee, with the exception of organisation $\mathrm{H}$, whose main source of income is from fees. Most organisations in the sample serve a broad client base, thereby not reserving access to interventions for any specific focus group. In exception to this, organisation $B$ reserves access for those younger than 35 years of age, and organisation $G$ focuses on providing interventions to unemployed individuals. The non-governmental organisations mostly have a local or regional focus, which is ascribed to funding and constitutional constraints. All the government organisations sampled as well as organisation D (an NPO) are part of a network of provincial and/or national offices. The regional and national offices tend to operate using standardised processes and structures. Organisation $\mathrm{H}$, a private sector organisation, is based in Cape Town, but the training interventions offered reach a national clientele.

TABLE 1: Profile of organisations in the sample

\begin{tabular}{|c|c|c|c|c|c|c|}
\hline $\begin{array}{l}\text { Organi- } \\
\text { sation }\end{array}$ & Form & Focus & Reach & Target group & Funding & $\begin{array}{c}\text { Fee } \\
\text { income }\end{array}$ \\
\hline$A$ & Govt & $\begin{array}{l}\text { General entrepreneu- } \\
\text { rial development }\end{array}$ & National & Broad & SA Govt & None \\
\hline B & Govt & $\begin{array}{l}\text { General entrepreneu- } \\
\text { rial development }\end{array}$ & National & $\begin{array}{c}\text { Broad, but } \\
\text { specific focus on } \\
\text { youth }\end{array}$ & SA Govt & $\begin{array}{l}\text { Commit- } \\
\text { ment fee }\end{array}$ \\
\hline C & Govt & $\begin{array}{l}\text { General entrepreneu- } \\
\text { rial development }\end{array}$ & Provincial & Broad & SA Govt & None \\
\hline D & NPO & $\begin{array}{l}\text { General entrepreneu- } \\
\text { rial development }\end{array}$ & National & Broad & $\begin{array}{c}\text { SA Govt/ } \\
\text { private/ } \\
\text { corporate SA }\end{array}$ & $\begin{array}{l}\text { Commit- } \\
\text { ment fee }\end{array}$ \\
\hline$\varepsilon$ & NPO & $\begin{array}{l}\text { General entrepreneu- } \\
\text { rialdevelopment }\end{array}$ & Local & Broad & $\begin{array}{c}\text { SA Govt/ } \\
\text { corporate SA / } \\
\text { university }\end{array}$ & $\begin{array}{l}\text { Commit- } \\
\text { ment fee }\end{array}$ \\
\hline $\mathrm{F}$ & NPO & $\begin{array}{l}\text { General entrepreneu- } \\
\text { rialdevelopment }\end{array}$ & Local & Broad & Foreign govt & None \\
\hline G & NPO & $\begin{array}{l}\text { Skills development } \\
\text { of the unemployed }\end{array}$ & Regional & $\begin{array}{l}\text { Broad, but } \\
\text { specific focus on } \\
\text { the unemployed }\end{array}$ & Various non-govt & $10 \%$ of cost \\
\hline $\mathrm{H}$ & PSO & $\begin{array}{l}\text { Training courses and } \\
\text { training educators }\end{array}$ & National & Broad & Proprietary & $\begin{array}{l}\text { Market- } \\
\text { related fee }\end{array}$ \\
\hline
\end{tabular}

Source: Compiled by the authors

\subsection{Overview of interventions}

TABLE 2 provides a brief overview of each organisation's approach to the interventions offered to its clients, indicating which organisations offer training, support services and/or mentoring interventions that contain an element of financial management. In most cases, financial 
management interventions are integrated with an organisation's broader entrepreneurial development interventions.

TABLE 2: Overview of financial management interventions offered

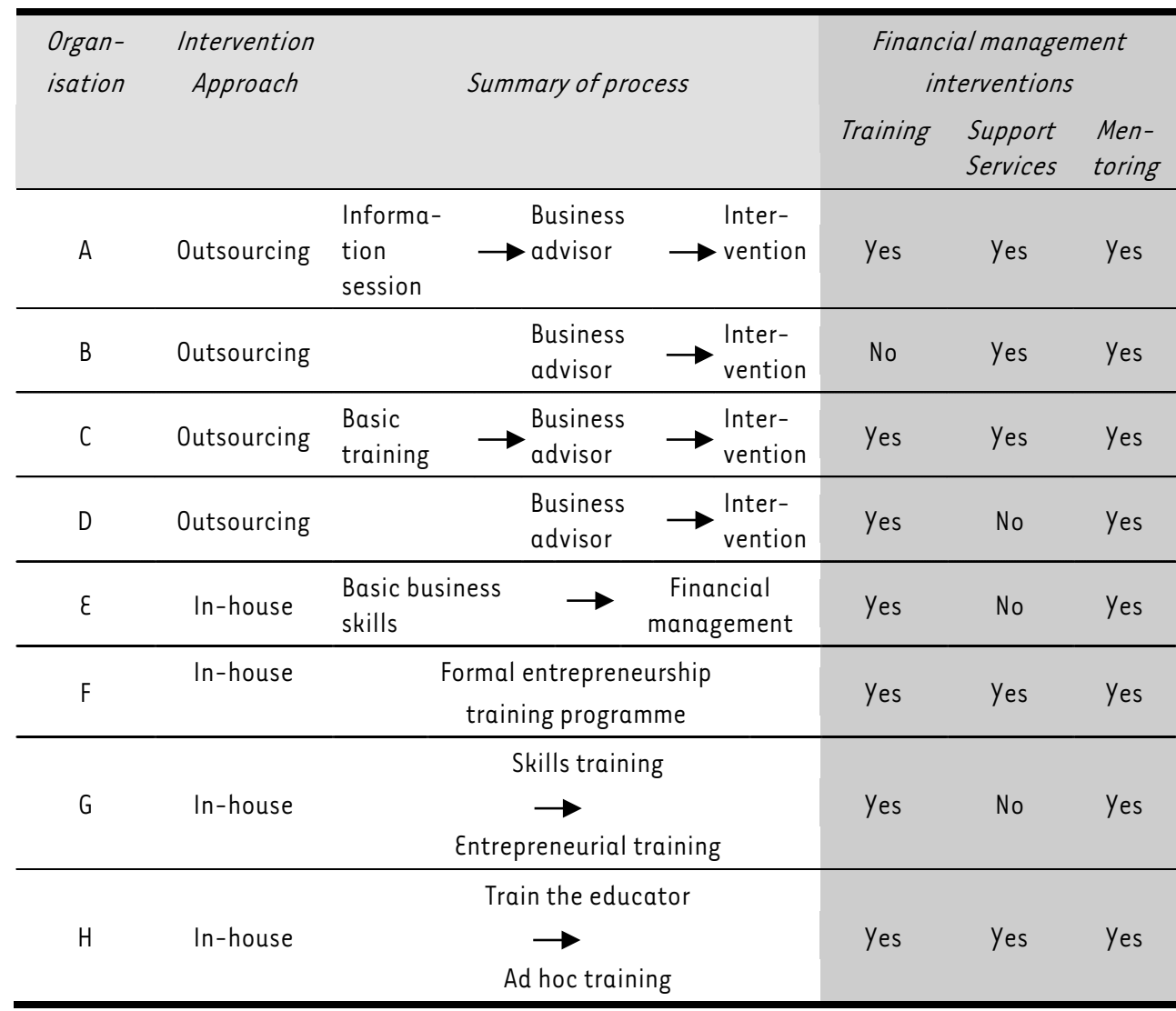

Source: Compiled by the authors

* Arrows indicate process flow

All the government organisations, namely organisations $A, B$ and C, and one NPO, organisation D, outsource small business interventions (and consequently financial management interventions) in a similar manner: once the clients' needs have been assessed by a business advisor, clients are referred to appropriate registered service providers for training support and/or mentoring. Thus, the majority of interventions are contracted out and the organisation can focus on monitoring the progress of the clients. This outsourcing approach focuses on transferring skills from the service provider to the client in a practical support context, rather than through traditional classroom-based training. The remainder of the organisations use an in-house approach to servicing clients, i.e. interventions (including financial management interventions) are presented to clients by staff employed by the organisation and skills are thus transferred to the client by an organisation's own staff. Organisation $\varepsilon$ requires clients first to take part in a basic business skills intervention before taking part in a financial management intervention, whereas organisation $\mathrm{F}$ offers a comprehensive formal entrepreneurship programme covering all aspects of entrepreneurship. Entrepreneurship training runs concurrently with the skills training 
offered by organisation G. Organisation H offers only ad hoc entrepreneurship training, as its key focus area is the training of educators.

\subsection{Financial management training interventions}

\subsubsection{Training courses offered that include financial management training}

\section{TABLE 3: Training courses offered at each organisation that includes financial management} training -1

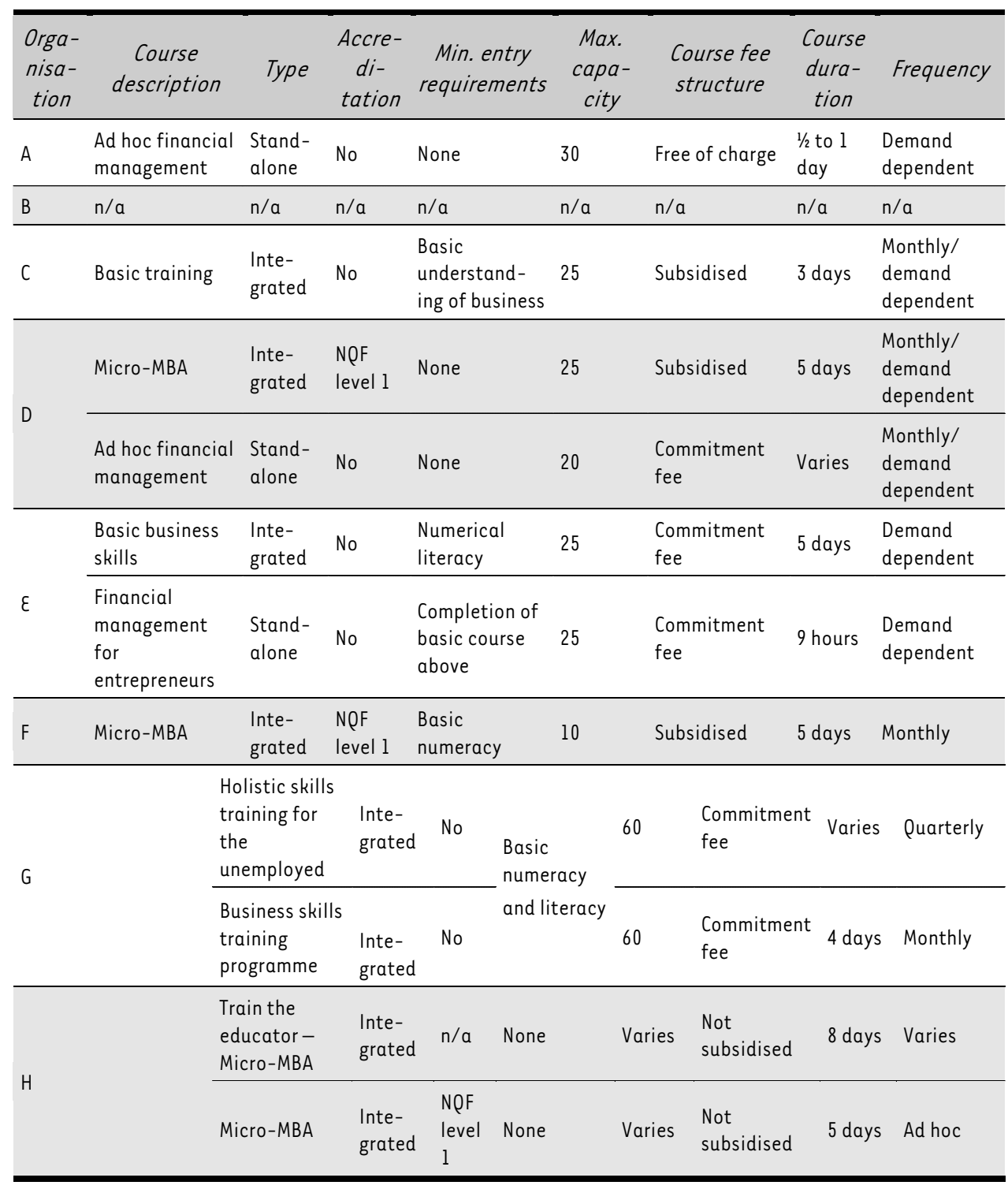

Source: Compiled by the authors 
TABLE 3 and TABLE 4 present a summary of the training courses offered by the selected organisations that include financial management training. It was found that very few organisations offer a dedicated (i.e. stand-alone) training course that specifically focuses on financial management, since most courses are integrated with an entrepreneurial or skills training course. Only one course is accredited at a National Qualification Framework (NQF) level, and entry requirements are mostly not prescriptive.

All but one organisation do not allow more than 30 persons at a time to attend a given training course. Most training courses are offered free of charge, although some request a commitment fee or subsidise a portion of the full cost of the course. The overall exposure to financial management training for the participants that attend training courses at these selected organisations is relatively short, and the frequency of the training courses mostly depends on demand.

Most of the organisations that follow the in-house approach to training also develop their courses in-house. The service providers that present ad hoc financial management training at organisations following the outsourcing approach are responsible for developing the course. The organisations that offer the Micro-MBA programme use the course material compiled and supplied by organisation H. The Micro-MBA programme comprises a five-day training course and a minimum three-month mentoring programme.

In most training courses, participants make limited use of financial data from their own businesses. The Micro-MBA programme is the exception: here own financial data is used intensively throughout the course. Very few organisations test participants formally after completion of the training course. Instead, other methods of evaluation, such as customer satisfaction forms, are used to measure the outcomes of the course. Most organisations attempt to track the progress of the participants after completion of the course, but cite this as challenging, owing to the time and administration it takes and the difficulty in getting hold of participants after completion of the course.

\section{TABLE 4: Training courses offered at each organisation that include financial management training - II}

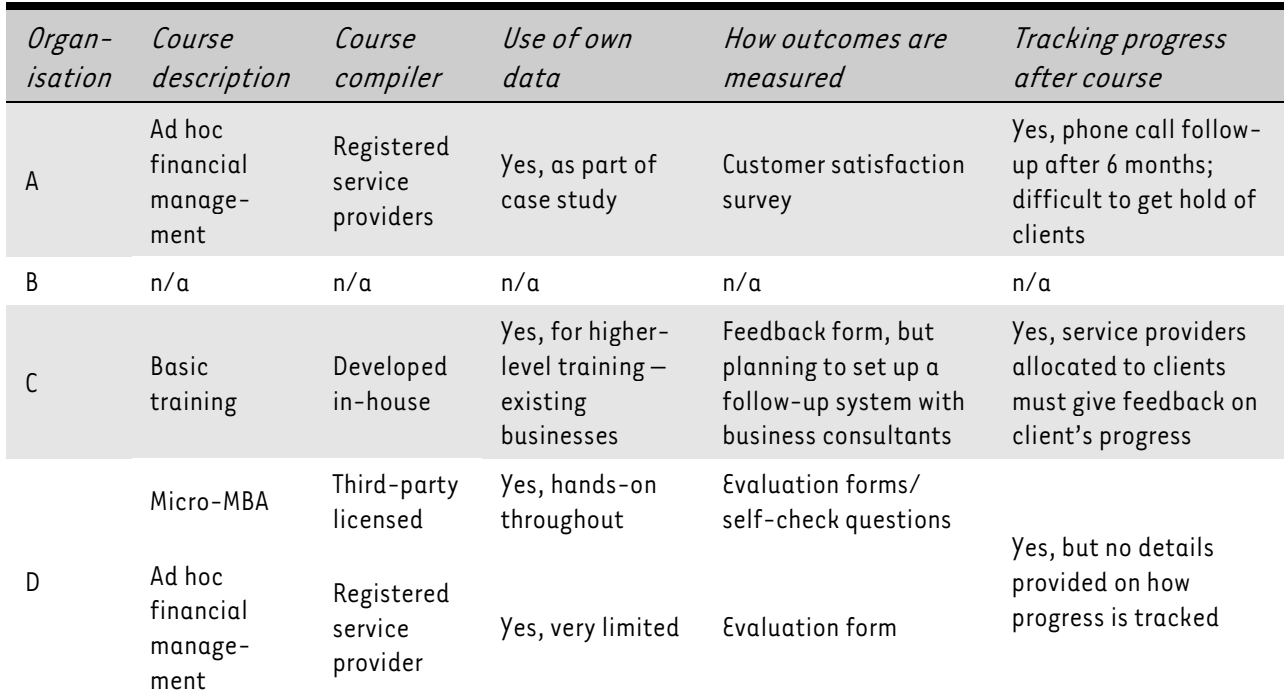




\begin{tabular}{|c|c|c|c|c|c|}
\hline $\begin{array}{l}\text { Organ- } \\
\text { isation }\end{array}$ & $\begin{array}{l}\text { Course } \\
\text { description }\end{array}$ & $\begin{array}{l}\text { Course } \\
\text { compiler }\end{array}$ & $\begin{array}{l}\text { Use of own } \\
\text { data }\end{array}$ & $\begin{array}{l}\text { How outcomes are } \\
\text { measured }\end{array}$ & $\begin{array}{l}\text { Tracking progress } \\
\text { after course }\end{array}$ \\
\hline \multirow[b]{2}{*}{$\varepsilon$} & $\begin{array}{l}\text { Basic } \\
\text { business } \\
\text { skills }\end{array}$ & $\begin{array}{l}\text { Developed } \\
\text { in-house }\end{array}$ & $\begin{array}{l}\text { No, only after } \\
\text { course when } \\
\text { drawing up own } \\
\text { business plan }\end{array}$ & Evaluation form & \multirow{2}{*}{$\begin{array}{l}\text { No, would like to, but } \\
\text { difficult to do in } \\
\text { practice }\end{array}$} \\
\hline & $\begin{array}{l}\text { Financial } \\
\text { manage- } \\
\text { ment for } \\
\text { entre- } \\
\text { preneurs }\end{array}$ & $\begin{array}{l}\text { Developed } \\
\text { in-house }\end{array}$ & Yes, very limited & $\begin{array}{l}\text { Evaluation form/ } \\
\text { limited self-check } \\
\text { questions }\end{array}$ & \\
\hline $\mathrm{F}$ & Micro-MBA & $\begin{array}{l}\text { Third-party } \\
\text { licensed }\end{array}$ & $\begin{array}{l}\text { Yes, hands-on } \\
\text { throughout }\end{array}$ & Self-check questions & $\begin{array}{l}\text { Yes, database } \\
\text { updated periodically }\end{array}$ \\
\hline G & $\begin{array}{l}\text { Holistic } \\
\text { skills } \\
\text { training for } \\
\text { unemployed } \\
\text { Business } \\
\text { skills } \\
\text { training } \\
\text { programme }\end{array}$ & $\begin{array}{l}\text { Custom- } \\
\text { designed } \\
\text { third party }\end{array}$ & $\begin{array}{l}\text { Yes, for } \\
\text { homework. } \\
\text { Most trainees } \\
\text { don't have own } \\
\text { business. }\end{array}$ & $\begin{array}{l}\text { Business plan marked, } \\
\text { tests written and } \\
\text { certificate received. }\end{array}$ & $\begin{array}{l}\text { Yes, database kept up } \\
\text { to date for reports to } \\
\text { funders. Often lose } \\
\text { track of past } \\
\text { participants though. }\end{array}$ \\
\hline \multirow[t]{2}{*}{ H } & $\begin{array}{l}\text { Train the } \\
\text { educator- } \\
\text { Micro MBA }\end{array}$ & $\begin{array}{l}\text { Developed } \\
\text { in-house }\end{array}$ & $\mathrm{n} / \mathrm{a}$ & \multirow[t]{2}{*}{ Self-check questions } & No \\
\hline & Micro-MBA & $\begin{array}{l}\text { Developed } \\
\text { in-house }\end{array}$ & $\begin{array}{l}\text { Yes, hands-on } \\
\text { throughout }\end{array}$ & & No \\
\hline
\end{tabular}

Source: Compiled by the authors

\subsubsection{Financial management topics covered}

TABLE 5 summarises the financial management-related topics each organisation covers in the various training courses it offers to participants. The topics covered are classified by the organisations as primary-focus ( 1 ) and secondary-focus (2) topics. Organisations that offer financial management training all expose their participants to training in drawing up a business plan. All the organisations that offer financial management training courses expose their participants to most of the financial management techniques required for achieving short-term goals of profitability and good cash-flow management. Organisations $D$ and $\varepsilon$ are the only organisations that expose trainees to some form of financial management techniques that are required for achieving the long-term financial management goals of investing, financing and solvency. 
TABLE 5: Financial management topics covered in training courses

\begin{tabular}{|c|c|c|c|c|c|c|c|c|c|c|c|c|c|c|c|}
\hline \multirow[b]{2}{*}{ 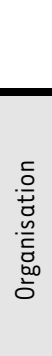 } & \multirow[b]{2}{*}{ 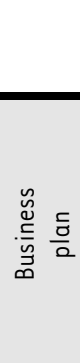 } & \multicolumn{10}{|c|}{ Short-term financial management skills } & \multicolumn{4}{|c|}{$\begin{array}{l}\text { Long-term financial } \\
\text { management skills }\end{array}$} \\
\hline & & 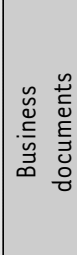 & 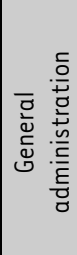 & 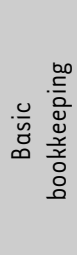 & 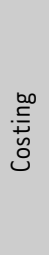 & 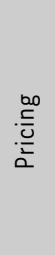 & 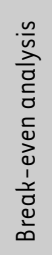 & 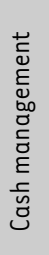 & 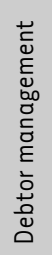 & 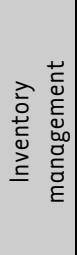 & 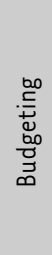 & 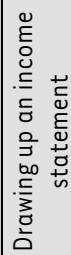 & 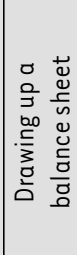 & 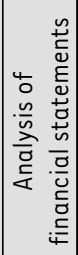 & 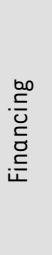 \\
\hline A & 1 & 1 & 2 & 1 & - & - & 1 & 1 & - & - & - & - & - & - & 1 \\
\hline B & $\stackrel{0}{\check{0}}$ & $\stackrel{0}{\check{\sigma}}$ & $\stackrel{\sigma}{c}$ & $\stackrel{0}{c}$ & $\stackrel{0}{c}$ & $\stackrel{0}{c}$ & $\stackrel{0}{\check{c}}$ & $\stackrel{0}{a}$ & $\stackrel{0}{a}$ & $\stackrel{0}{c}$ & $\stackrel{0}{\check{c}}$ & $\stackrel{0}{\check{0}}$ & $\stackrel{0}{c}$ & $\stackrel{0}{c}$ & $\stackrel{0}{\square}$ \\
\hline C & 1 & 1 & - & - & - & - & - & - & - & - & 1 & - & - & - & - \\
\hline $\mathrm{D}$ & 1 & - & 1 & 1 & 1 & 1 & 1 & 1 & 1 & 2 & 1 & - & - & 2 & - \\
\hline$\varepsilon$ & 1 & 1 & 1 & 1 & 1 & 1 & 1 & 1 & 1 & 1 & 1 & 1 & 1 & - & 1 \\
\hline $\mathrm{F}$ & 1 & 2 & 2 & - & 1 & 1 & 1 & 1 & l & 1 & 1 & - & - & - & - \\
\hline G & 1 & 2 & - & 1 & 2 & 2 & - & 2 & - & 2 & 2 & - & - & - & - \\
\hline $\mathrm{H}$ & 1 & - & 1 & - & 1 & l & 1 & 1 & 1 & 1 & 1 & - & - & - & - \\
\hline
\end{tabular}

Source: Compiled by the authors

* $1=$ Primary-focus topics; $2=$ Secondary-focus topics

\subsection{Financial management support services}

TABLE 6 summarises the financial management support services that each organisation offers. Governmental organisations, using the outsourcing model, provide financial management support interventions through the use of voucher programmes. A voucher programme, in the financial management context, entails a client being awarded vouchers that provide them with access to an approved provider of financial management support services. The provider of financial management support services is generally a financial management practitioner, for example, an accountant or tax consultant, that has been approved to service small business clients. Clients therefore receive subsidised support in resolving financial management issues pertaining to their business, for example, setting up accounting systems or cleaning up financial records. During such interventions the service provider should transfer knowledge to the client that will enable them to better manage their financial affairs. In the sample, the NPOs and private organisations provide little or no financial management support services. Organisations $\mathrm{F}$ and $\mathrm{H}$, for example, provide support services only on an informal and ad hoc basis for clients that have participated in training programmes. 
TABLE 6: Support services - financial management related

\begin{tabular}{|c|c|c|c|}
\hline $\begin{array}{l}\text { Organ- } \\
\text { isation }\end{array}$ & Name & Description & $\begin{array}{l}\text { Fee } \\
\text { structure }\end{array}$ \\
\hline A & Voucher programme & Once-off financial clean-up service & Subsidised \\
\hline B & Voucher programme & $\begin{array}{l}\text { Turn-around strategy voucher-includes financial } \\
\text { management voucher }\end{array}$ & Subsidised \\
\hline 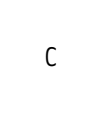 & Voucher programme & $\begin{array}{l}\text { Financial management problem-specific consulting; } \\
\text { once-off financial clean-up and financial systems } \\
\text { development; business plan }\end{array}$ & Subsidised \\
\hline D & $\mathrm{n} / \mathrm{a}$ & $\mathrm{n} / \mathrm{a}$ & $\mathrm{n} / \mathrm{a}$ \\
\hline$\varepsilon$ & $\mathrm{n} / \mathrm{a}$ & $\mathrm{n} / \mathrm{a}$ & $\mathrm{n} / \mathrm{a}$ \\
\hline $\mathrm{F}$ & Business plan service & Ad hoc support in developing business plan & Free \\
\hline G & $\mathrm{n} / \mathrm{a}$ & $\mathrm{n} / \mathrm{a}$ & $\mathrm{n} / \mathrm{a}$ \\
\hline $\mathrm{H}$ & $\begin{array}{l}\text { Ad hoc support to } \\
\text { educators and } \\
\text { entrepreneurs }\end{array}$ & $\begin{array}{l}\text { Open door policy-assistance offered for any of the } \\
\text { educators }\end{array}$ & Free \\
\hline
\end{tabular}

Source: Compiled by the authors

\subsection{Financial management mentoring}

TABLE 7 summarises mentoring interventions offered by each sample organisation that contain some element of financial management. All the sample organisations find mentorship interventions challenging to develop and sustain. Although all sample organisations offer some form of mentorship intervention, the nature of and approach to mentorship differ considerably. The nature of the mentoring offered by all the organisations, except where the Micro MBA programme is used, is very broad and not primarily focused on financial management. Organisations $D$ and $G$ indicated that they wish to expand their mentorship interventions to also provide better financial management mentoring.

\section{TABLE 7: Financial management-related mentoring}

\begin{tabular}{|c|c|c|c|c|}
\hline $\begin{array}{l}\text { Organ- } \\
\text { isation }\end{array}$ & Name & Description & $\begin{array}{l}\text { Frequency of } \\
\text { meetings }\end{array}$ & Fee structure \\
\hline A & Ad hoc mentoring programme & $\begin{array}{l}\text { Provided by service providers } \\
\text { when needed }\end{array}$ & $\begin{array}{l}\text { Depends on } \\
\text { need of mentee }\end{array}$ & Subsidised \\
\hline B & Volunteer mentorship programme & $\begin{array}{l}\text { Concurrent meetings held with } \\
\text { all mentees in programme at } \\
\text { set venue }\end{array}$ & Monthly & Free of charge \\
\hline C & $\begin{array}{l}\text { Ad hoc mentoring (Programme is } \\
\text { in the process of being } \\
\text { restructured) }\end{array}$ & $\begin{array}{l}\text { General mentoring when } \\
\text { needed. }\end{array}$ & $\begin{array}{l}\text { Depends on } \\
\text { need of mentee }\end{array}$ & Subsidised \\
\hline$D$ & Micro-MBA mentorship component & Part of Micro-MBA package & $\begin{array}{l}\text { At least once } \\
\text { monthly for } 3 \\
\text { months }\end{array}$ & $\begin{array}{l}\text { Part of } \\
\text { training course } \\
\text { fee }\end{array}$ \\
\hline$\varepsilon$ & Ad hoc mentoring & $\begin{array}{l}\text { General mentoring when } \\
\text { needed. }\end{array}$ & $\begin{array}{l}\text { Depends on } \\
\text { need of mentee }\end{array}$ & Free of charge \\
\hline
\end{tabular}




\begin{tabular}{|c|c|c|c|c|}
\hline $\begin{array}{l}\text { Organ- } \\
\text { isation }\end{array}$ & Name & Description & $\begin{array}{c}\text { Frequency of } \\
\text { meetings }\end{array}$ & Fee structure \\
\hline $\mathrm{F}$ & Micro-MBA mentorship component & Part of Micro-MBA package & $\begin{array}{l}\text { At least once } \\
\text { monthly for } 3 \\
\text { months }\end{array}$ & $\begin{array}{l}\text { Part of } \\
\text { training course } \\
\text { fee }\end{array}$ \\
\hline G & On-site business mentoring & $\begin{array}{l}\text { Only provided to two small } \\
\text { businesses operating from } \\
\text { premises }\end{array}$ & $\begin{array}{l}\text { Depends on } \\
\text { need of mentee } \\
\text { - daily }\end{array}$ & $\begin{array}{l}\text { Management } \\
\text { fee and rental }\end{array}$ \\
\hline H & Micro-MBA mentorship component & Part of Micro-MBA package & $\begin{array}{l}\text { At least once } \\
\text { monthly for } 3 \\
\text { months }\end{array}$ & $\begin{array}{l}\text { Part of } \\
\text { training course } \\
\text { fee }\end{array}$ \\
\hline
\end{tabular}

Source: Compiled by the authors

\subsection{Involvement of members of the accounting profession in financial management training, support services and mentoring}

TABLE 8 provides an overview of the nature and extent of the current involvement of members of the accounting profession in financial management training, support services and mentoring at the selected organisations as well as the opportunities identified by these organisations for members of the accounting profession to get involved.

TABLE 8: Current involvement and opportunities identified for involving the accounting profession

\begin{tabular}{|c|c|c|c|c|c|}
\hline $\begin{array}{l}\text { Organ- } \\
\text { isation }\end{array}$ & Type & \multicolumn{2}{|c|}{$\begin{array}{l}\text { Current involvement of } \\
\text { accounting profession? } \\
\text { Comments }\end{array}$} & \multicolumn{2}{|c|}{$\begin{array}{l}\text { Interest in assistance from accounting profession? } \\
\text { Comments }\end{array}$} \\
\hline \multirow{3}{*}{ A } & Training & NO & - & yEs & $\begin{array}{l}\text { But not suited for a majority of clients that have } \\
\text { a limited understanding of business }\end{array}$ \\
\hline & $\begin{array}{l}\text { Support } \\
\text { services }\end{array}$ & yદડ & $\begin{array}{l}\text { Accountants - } \\
\text { service providers }\end{array}$ & yદs & Same as above \\
\hline & Mentoring & yદs & $\begin{array}{l}\text { Accountants - } \\
\text { service providers }\end{array}$ & yદs & Same as above \\
\hline \multirow{3}{*}{ B } & Training & N/A & - & N/A & - \\
\hline & $\begin{array}{l}\text { Support } \\
\text { services }\end{array}$ & yEs & $\begin{array}{l}\text { Accountants - } \\
\text { service providers }\end{array}$ & yદS & $\begin{array}{l}\text { Accountants - service providers } \\
\text { Initially for bookkeeping assistance, later higher- } \\
\text { level assistance }\end{array}$ \\
\hline & Mentoring & NO & - & yEs & $\begin{array}{l}\text { Specialised skills provide better knowledge to } \\
\text { transfer }\end{array}$ \\
\hline \multirow{3}{*}{ C } & Training & NO & - & yES & Accounting students - owing to limited budget \\
\hline & $\begin{array}{l}\text { Support } \\
\text { services }\end{array}$ & yદs & $\begin{array}{l}\text { Accountants - } \\
\text { service providers }\end{array}$ & yદs & $\begin{array}{l}\text { Accountants - affiliated with professional body } \\
\text { Accounting students - cheaper, no conflict of } \\
\text { interest }\end{array}$ \\
\hline & Mentoring & NO & - & N/A & $\begin{array}{l}\text { Current mentoring programme is in the process of } \\
\text { being restructured. }\end{array}$ \\
\hline
\end{tabular}




\begin{tabular}{|c|c|c|c|c|c|}
\hline \multirow[t]{2}{*}{$\begin{array}{l}\text { Organ- } \\
\text { isation }\end{array}$} & Type & \multicolumn{2}{|c|}{$\begin{array}{c}\text { Current involvement of } \\
\text { accounting profession? } \\
\text { Comments }\end{array}$} & \multicolumn{2}{|c|}{$\begin{array}{l}\text { Interest in assistance from accounting profession? } \\
\text { Comments }\end{array}$} \\
\hline & Other & & & yEs & $\begin{array}{l}\text { Registered accountants - to give credibility to } \\
\text { new corporate enterprise development funding } \\
\text { initiatives }\end{array}$ \\
\hline \multirow{4}{*}{ D } & Training & yES & $\begin{array}{l}\text { Accountants - } \\
\text { workshops }\end{array}$ & yES & $\begin{array}{l}\text { Accountants - for high-level financial } \\
\text { management skills, industry experience preferred }\end{array}$ \\
\hline & $\begin{array}{l}\text { Support } \\
\text { services }\end{array}$ & N/A & - & yEs & $\begin{array}{l}\text { Accounting students - with other students from } \\
\text { other fields of study }\end{array}$ \\
\hline & Mentoring & NO & - & yદs & $\begin{array}{l}\text { Involve accounting profession when necessary } \\
\text { once proposed mentorship programmes are } \\
\text { implemented. }\end{array}$ \\
\hline & Other & & - & yEs & Accounting academics - train the educator \\
\hline \multirow{3}{*}{$\varepsilon$} & Training & yES & $\begin{array}{l}\text { Accounting } \\
\text { academic-stand- } \\
\text { alone course }\end{array}$ & yEs & Accounting academics - expand current course \\
\hline & $\begin{array}{l}\text { Support } \\
\text { services }\end{array}$ & N/A & - & yES & Accounting profession - accounting clinic \\
\hline & Mentoring & NO & - & yES & $\begin{array}{l}\text { Accounting profession - no capacity in-house to } \\
\text { run programme }\end{array}$ \\
\hline \multirow{4}{*}{$\mathrm{F}$} & Training & NO & - & yES & $\begin{array}{l}\text { Accounting profession - no capacity in-house to } \\
\text { develop clients further } \\
\text { Reservations regarding accounting students } \\
\text { Trainee accountant - assistance in groups }\end{array}$ \\
\hline & $\begin{array}{l}\text { Support } \\
\text { services }\end{array}$ & NO & - & yES & $\begin{array}{l}\text { Accounting clinic - link up with planned business } \\
\text { hub }\end{array}$ \\
\hline & Mentoring & NO & - & yEs & $\begin{array}{l}\text { Accounting profession - expand on current } \\
\text { programme }\end{array}$ \\
\hline & Other & & & yES & Accounting profession - train the educator \\
\hline \multirow[t]{4}{*}{ G } & $\begin{array}{l}\text { Training } \\
\text { Support } \\
\text { services }\end{array}$ & NO & - & yદs & $\begin{array}{l}\text { Accounting profession - must simplify } \\
\text { Accounting profession -bookkeeping and } \\
\text { knowledge transfer }\end{array}$ \\
\hline & Mentoring & NO & - & yєs & \\
\hline & Training & yES & $\begin{array}{l}\text { Accountants - } \\
\text { trained as } \\
\text { educators }\end{array}$ & & $\begin{array}{l}\text { Knowledge gap too big between accountants and } \\
\text { clients. Have to channel knowledge into a simple } \\
\text { process. }\end{array}$ \\
\hline & $\begin{array}{l}\text { Support } \\
\text { services }\end{array}$ & NO & - & & \\
\hline
\end{tabular}

Source: Compiled by the authors 


\subsubsection{Current involvement of accounting profession in financial management interventions}

Training courses: Only three organisations have members of the accounting profession involved in financial management training. Organisation $D$ makes use of at least two accountants to run certain workshops. Organisation $\varepsilon$ uses an accounting academic who presents a portion of the basic business skills course and presents the stand-alone financial management course. Organisation $G$ used trained accountants as educators in the past, but it is uncertain whether these accountants are still actively involved in training.

Support services: Only three organisations have members of the accounting profession involved in offering support services. Organisation A uses accountants who are registered service providers to perform once-off financial clean-up services for entrepreneurs at a fee. Organisation B currently uses accountants as service providers for providing support services. Organisation $C$ uses only a few accounting firms to assist with the bookkeeping voucher system, and these accounting firms are selective as to which clients they will take on.

Mentoring: Organisation A has a few accountants who are registered service providers who will act as mentors, but they are not trained as mentors. None of the other organisations that offer mentoring have members of the accounting profession involved as mentors.

\subsubsection{Interest in involving the accounting profession in financial management interventions}

Training: All the organisations that offer training in financial management, with the exception of organisation $\mathrm{H}$, indicated an interest in involving and/or expanding the current involvement of members of the accounting profession in financial management training for participants. Organisation A indicated that the assistance may be suitable for training clients with more established businesses, but believes it would not be effective for clients that have a limited understanding of business. This comment also applies to providing support services and mentoring. Owing to a limited budget and an inability to pay market-related fees to professionals, organisation $C$ indicated an interest in involving accounting students as service providers to assist in regular financial management training for existing businesses. Organisation $D$ indicated that assistance from accountants is required with the following: interpretation of financial statements, cash flow management, differentiating cash flow from profit and simplifying financial terminology. They also indicated that own business data should be used during these training interventions to make it tangible for business owners. They recommended that accountants be proficient in a variety of industries, and industry-specific workshops. Organisation $\varepsilon$ indicated an interest in expanding the involvement of accounting academics in the training course as well as involving accounting students. Organisation $F$ indicated a lack of capacity to support established businesses and wishes to involve members of the accounting profession, on condition that the interventions should be properly planned to ensure effectiveness. The organisation has, for example, reservations about involving students because of the risk of losing continuity, since students may not be available throughout the year and will move on after their studies. A workable model should be developed if students are to become involved. Volunteers who can assist for a few months at a time are preferred. There is also an interest in involving trainee accountants, where they can, for example, work in a group with clients, assisting a number of people simultaneously. Organisation $\mathrm{G}$ indicated an interest 
in involving members of the accounting profession, but indicated that they should be able to simplify complex concepts.

Support Services: All the organisations, except for organisation $\mathrm{H}$, indicated an interest in either commencing or improving their financial management support services to clients by involving members of the accounting profession in providing support services. Organisation B indicated that the more professionals were involved, the more value could be added to the service it offers to its clients. Accountants can register as service providers and can find a niche for themselves in the voucher programme. This organisation's clients may initially only need bookkeeping assistance or skills development, but higher-level assistance will be required when these businesses grow. Organisation $C$ indicated that it would prefer working with accounting firms that are affiliated to a professional body, as these firms' reputational risk would prevent them from providing unnecessary services to clients. In the past, problems were experienced with unscrupulous service providers selling goods and providing services that clients did not need and these service providers also prevented knowledge transfer from taking place to ensure client dependency. Organisation $\mathrm{C}$ has indicated that it cannot afford professionals to perform these services. If accounting students become involved in providing support services, knowledge transfer could take place, because there would be no conflict of interest (i.e. there is no vested interest in not transferring the skills). Students are also not as expensive as professionals and they can register as individual service providers in their personal capacity.

Organisation $D$ indicated an interest in expanding past initiatives where coordinated groups of university students from various fields of study linked up with service clients. Organisation $\varepsilon$ wishes to develop support services in future, in conjunction with members of the accounting profession, to be an extension of the stand-alone financial management skills course. This could be in the form of an accounting clinic. Organisation $F$ is planning to set up a business hub, and an accounting-clinic-type model could link up with this business hub. This organisation believes that clients should pay for services at the business hub, but that clients must benefit more from this service than from what they would get somewhere else. Organisation $G$ regards support services and mentoring as one service (see comments under mentoring below).

Mentoring: All but one organisation indicated an interest in involving the accounting profession in financial management mentoring. Accountants can register individually as service providers to be mentors at organisation $A$, but accountants might not be appropriate to mentor the majority of the clients, who operate on too basic a level to justify professional mentoring. Organisation $B$ indicated that it would be interested in professionals being involved in mentoring, since the more skilled and specialised the mentor, the better the knowledge that is imparted. Organisation $D$ is considering developing various forms of mentorship such as peerto-peer mentoring (or group mentorship) and using retired executives as mentors. Involving the accounting profession could also be an option if the need arises. Although organisation $\varepsilon$ sees value in mentoring, it does not have the capacity to formalise a mentorship programme and would be interested in evaluating options for involving the accounting profession in this regard. Organisation $F$ indicated an interest in expanding the current mentoring programme to involve members of the accounting profession. Organisation $G$ is interested in involving members of the accounting profession in mentoring its current mentees, but there must be a commitment from the mentors for at least a year, as it is found that the enthusiasm for such an initiative tends to taper off over time. Organisation $G$ defines mentoring more broadly as including support. In the case of bookkeeping, for example, the mentor assists with the bookkeeping but at the same time transfers these skills to mentees so that they can do it for themselves after, say, one year. This type of mentoring should take place regularly. 
Other opportunities indicated: Organisation C indicated that involvement of registered accountants with its organisation could give credibility to enterprise development funding initiatives. Organisation $F$ indicated an interest in the accounting profession assisting in training the educators of its organisation to enhance the skills level of in-house staff, as its staff members currently have limited experience in financial management-related fields.

Organisation $\mathrm{H}$ is the only organisation that indicated that it would not be interested in involving the accounting profession in training, support services or mentoring initiatives. The representative of organisation $\mathrm{H}$ provided the following reasons for this:

\begin{abstract}
The greatest challenge in developing this [Micro-MBA] course over the past few years wasn't so much what people needed to know but rather in making something so simple that anyone can understand it. Our experience has shown that training and/or mentoring of small businesses by successful business people is not recommended, as the mentor usually attempts to impose their systems and thinking on the mentee. In reality there is too big a gap between the two parties. It is almost as if they are speaking different languages. There has however been limited success with using highly qualified persons as trainers/mentors. An intervention will only be successful when the highly qualified person is teachable as it is very hard with someone with a PhD or a Chartered Accountant to come and sit in a thing like this and say 'I am here to learn', they usually feel they are here to teach. Highly skilled people can become tremendous trainers/mentors if they can be taught how to channel their wealth of information into a simple process, into something like the Micro-MBA course.
\end{abstract}

From the above, it is clear that the representative from this organisation is hesitant to allow accountants to train, support and/or mentor entrepreneurs, owing to the knowledge gap that exists between a highly qualified accountant and an entrepreneur with limited education. The accountants that would like to become involved would need to go back to the 'basics' of financial management to ensure that knowledge is transferred at a level understandable to the small business owner.

\title{
4. CONCLUSION AND RECOMMENDATIONS
}

This study found that the financial management training, support services and mentoring initiatives offered by the selected organisations vary significantly and in most cases are ad hoc and not adequately developed. This is particularly true for support services and mentoring. It is also clear that the selected organisations are intent on receiving assistance from the various members of the accounting profession to supplement and help with the financial management training, support services and/or mentoring currently offered. Based on previous experience, some organisations are specific in their requirements regarding the nature and extent of the involvement, whereas other organisations are less prescriptive, but do indicate certain reservations. Each organisation in the sample has its unique objectives, structure and services that it offers to its target group. These organisations have identified either specific or broader areas in which members of the accounting profession could assist. This research clearly indicates a specific need for the accounting profession's involvement in financial skills development by organisations that support and develop the entrepreneurial skills of small businesses.

The findings of this study contribute to the body of knowledge relating to CSR in the South African business sector, in accordance with Hamann's (2006:179-182) research agenda, as specific and relevant small business development challenges relating to financial management skills development in the Greater Cape Town area are identified. This knowledge obtained from 
an external societal stakeholder perspective can assist members of the accounting profession to approach their CSR strategically and effectively. Using their expertise in financial management skills effectively in order to meet their CSR could assist members of the accounting profession to improve what Porter refers to as the context of its competitive advantage (Garriga \& Mele, 2004:54-55, Porter \& Kramer, 2006). Accounting firms might, for example, find that strategic interaction with small businesses as part of their CSR might also allow them to innovate and design financial management services that can serve clients at the bottom of the economic pyramid (Garriga \& Mele, 2004: 55).

Hamann's (2006:188-190) proposal to research the practical implementation of CSR is also addressed in this study. Based on the findings of this study, the following recommendations are made that will assist members of the accounting profession with the practical implementation of CSR to enhance the development of financial management skills in small businesses:

- Ladzani and Van Vuuren (2002:158) state that both the public and the private sector should support and strengthen the current small business initiatives of established organisations. Accordingly, the accounting profession should move towards an integrated approach to supporting small businesses and should focus its resources and energy on supporting targeted small business financial management initiatives in a way that ensures continuity and cross-disciplinary collaboration with current initiatives. Members of the accounting profession must thus work together with existing small business support organisations and identify the organisations' and small businesses' support needs. They must also make use of the infrastructure of the small business support organisations (to avoid duplicating services) and take into account the small business support organisation's knowledge of and experience in the small business environment to ensure that knowledge transfer takes place effectively.

- Members of the accounting profession must be able to simplify financial management terminology, concepts and processes, and communicate in language understandable to the person(s) they are interacting with. At the same time they must be willing to learn about the small business environment. It is proposed that an introductory workshop or guidelines on working in the small business environment is made available to members of the accounting profession before they become involved in these initiatives.

- A platform should exist from which members of the accounting profession involved in small business support initiatives could network in order to share knowledge and experiences, instead of working in isolation.

- To ensure the continuity and sustainability of initiatives in which members of the accounting profession become involved, these initiatives should operate under a cohesive framework, especially in cases where accounting students and trainee accountants are involved. An independent framework would also minimise any potential conflict of interest that could arise when knowledge transfer takes place between members of the accounting profession and the small business owner.

- Cognisance must be taken of the budgetary constraints of small business support organisations and that CSR initiatives in conjunction with these organisations will require members of the accounting profession to expend financial and human resources. Funding models could, however, be developed so that the members of the accounting profession that provide professional services are at least partially remunerated for their efforts and/or earn B-BBEE points for providing their professional services. This could contribute 
toward the sustainability for this type of CSR initiative. Care should be taken not to compromise independence and the quality of the service, while ensuring that it is still being affordable to the organisation that provides small business support.

Herrington, Kew and Kew (2010:157) identified the need for accounting clinics to offer specialised but affordable advice and services. The appropriateness of an accounting clinic as a vehicle for enabling financial management support to small businesses falls outside of the scope of this article, but is an area for future research. Accounting clinics have not been specifically defined in the literature, and thus the proposed framework of involving members of the accounting profession recommended above could be researched further to potentially form the basis of an effective accounting clinic model. This exploratory study was also limited to the Greater Cape Town area in the Western Cape and this research can be extended to other parts of South Africa to identify similarities and differences in issues concerning the financial management skills development of small businesses and the potential of effectively involving the accounting profession in this process.

\section{LIST OF REFERENCES}

Babbie, E.R. \& Mouton, J. (2001). The Practice of Social Research, South African Edition. Oxford: Oxford University Press.

Benbasat, I., Goldstein, D.K. \& Mead, M. (1987). The Case Research Strategy in Studies of Information Systems. MIS Quarterly, 11(3), pp. 369-386.

Berry, A., Von Blottnitz, M., Cassim, R., Kesper, A., Rajaratnam, B. \& Van Seventer, D.E. (2002). The Economics of SMMES in South Africa. Johannesburg: Trade and Industrial Policy Strategies.

Cassell, C. \& Symon, G. (2004). Essential Guide to Qualitative Methods in Organizational Research. London: Sage Publications.

Crowther, D. \& Aras, G. (2008). Corporate Social Responsibility. Denmark: Ventus Publishing

Department of Trade and Industry (DTI). (2003). The Integrated Small Business Development Strategy in South Africa 2004-2014. [Online] Available: http://intertest.dwa.gov.za

/WAR/WAR_WEBSITE_DOCS/Edition_6/FINAL_DOCUMENTS/Extra_reading/Integrated_Small_Business

Strategy.pdf. (Accessed 2 August 2011).

Department of Trade and Industry (DTI). (2007). Codes of Good Practice on Black Economic

Empowerment. [Online] Available: http://www.dti.gov.za/economic_empowerment/

docs/generic_code_pl.pdf. (Accessed 28 March 2012).

Douhan, R., Eliasson, G. \& Henrekson, M. (2007). Israel M. Kirzner: An Outstanding Austrian

Contributor to the Economics of Entrepreneurship. Small Business Economics, 29(1), pp. 213-223.

Garriga, E. \& Mele, D. (2004) Corporate Social Responsibility Theories: Mapping the Territory. Journal of Business Ethics, 53(1-2), pp. 51-71.

Government of South Africa. (1996). National Small Business Act (Act 102 of 1996). Government Printers: Pretoria.

Government of South Africa. (2010). The New Growth Path: The Framework. [Online] Available: http://www.info.gov.za/view/DownloadFileAction?id=135748. (Accessed 10 August 2011). 
Hamann, R. (2006). Can Business make Decisive Contributions to Development? Towards a Research Agenda on Corporate Citizenship and Beyond. Development Southern Africa, 23(2), pp. 175-195.

Herrington, M., Kew, J. \& Kew, P. (2010). Tracking Entrepreneurship in South Africa: A GEM Perspective. Cape Town: The Centre for Innovation and Entrepreneurship, University of Cape Town Graduate School of Business.

Kelley, D.J., Bosma, N. \& Amorós, J.E. (2011). Global Entrepreneurship Monitor: 2010 Global Report. Babson Park: Global Entrepreneurship Research Association.

Kiggundu, M.N. (2002). Entrepreneurs and Entrepreneurship in Africa: What is Known and What Needs to be Done. Journal of Developmental Entrepreneurship, 7(3), pp. 239-258.

Kirzner, I.M. (2009). The Alert and Creative Entrepreneur: A Clarification. Smal/ Business Economics, 32(2), pp. 145-152.

Ladzani, W.M. \& Van Vuuren, J.J. (2002). Entrepreneurship Training for Emerging SMEs in South Africa. Journal of Small Business Management, 40(2), pp. 154-161.

Maas, G. \& Herrington, M. (2006). Global Entrepreneurship Monitor: South African Executive Report 2006. Cape Town: The Centre for Innovation and Entrepreneurship, University of Cape Town Graduate School of Business.

Marx, J., De Swardt, C., Beaumont-Smith, M., Naicker, B. \& Erasmus, P. (2004). Financial

Management in Southern Africa. Cape Town: Pearson.

Orford, J., Herrington, M. \& Wood, ع. (2004). Global Entrepreneurship Monitor: 2004 South African

Executive Report. Cape Town: The Centre for Innovation and Entrepreneurship, University of Cape Town Graduate School of Business.

Porter, M.E. \& Kramer, M.R. (2006). Strategy \& Society: The Link Between Competitive Advantage and Corporate Social Responsibility. Harvard Business Review, 84(12), pp. 78-92

Provincial Government of the Western Cape. (2011). Red Door Small Business Advice Centres:

Overview. [Online] Available: http://www.capegateway.gov.za/reddoor. (Accessed 4 0ctober 2011).

Robson, C. (2002). Real World Research: A Resource for Social Scientists and PractitionerResearchers. Oxford: Blackwell Publishers.

Scholtz, R.W. \& Tietje, 0. (2002). Embedded Case Study Methods: Integrating Quantitative and Qualitative Knowledge. Thousand Oaks: Sage Publications.

Schwarze, C.L. (2008). Involving the Accounting Profession in the Development of Financial Management Skills of Micro-Enterprise Owners in South Africa. Meditari Accounting Research, 16(2), pp. 139-151.

South African Institute of Chartered Accountants (SAICA). (2011). Black Entrepreneurship Initiative Kicks Off with a Record 31 Partnerships. Press release. [Online] Available:

https://www.saica.co.za/News/NewsArticlesandPressmediareleases/tabid/695/itemid/2889/langua ge/en-ZA/Default.aspx. (Accessed 2 August 2011).

South African Institute of Chartered Accountants (SAICA) Enterprise Development. (2011). The Hope Factory home page. [Online] Available: http://www.thehopefactory.co.za. (Accessed 4 0ctober 2011).

Terry, G. (2008). Green: Why Corporate Leaders need to Embrace Sustainability to ensure Future Profitability. Johannesburg: SAICA. 
United West Sussex: John Wiley \& Sons. Nations (UN). (2010). Economic Recovery Strategies Must Prioritize Job Creation, Says UN Labour Agency. UN News Centre. [Online] Available:

http://www.un.org/apps/news/story.asp?NewsID=35825\& Cr=labour\&Crl. (Accessed 2 August 2011).

Visser, W., Matten, D., Pohl, M. \& Tolhurst, N. (2010). The A-Z of Corporate Social Responsibility. 